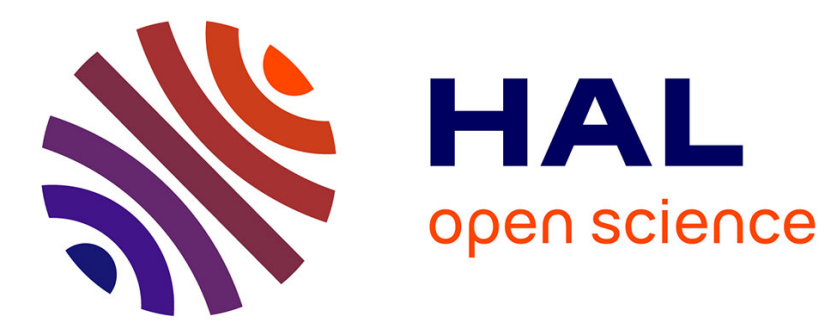

\title{
The determinants of aggregate creditors' voluntary liquidations
}

Peter Lloyd Jones

\section{To cite this version:}

Peter Lloyd Jones. The determinants of aggregate creditors' voluntary liquidations. Applied Economics, 2011, 45 (10), pp.1321-1330. 10.1080/00036846.2011.617695 . hal-00762895

\section{HAL Id: hal-00762895 \\ https://hal.science/hal-00762895}

Submitted on 9 Dec 2012

HAL is a multi-disciplinary open access archive for the deposit and dissemination of scientific research documents, whether they are published or not. The documents may come from teaching and research institutions in France or abroad, or from public or private research centers.
L'archive ouverte pluridisciplinaire HAL, est destinée au dépôt et à la diffusion de documents scientifiques de niveau recherche, publiés ou non, émanant des établissements d'enseignement et de recherche français ou étrangers, des laboratoires publics ou privés. 


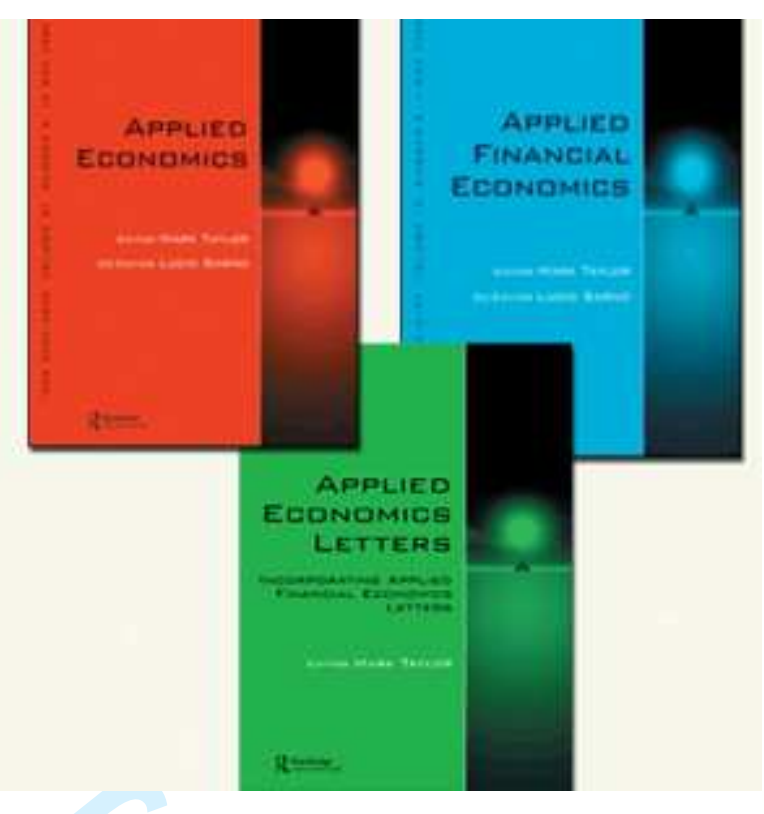

\section{The determinants of aggregate creditors' voluntary liquidations}

\begin{tabular}{|c|c|}
\hline Journal: & Applied Economics \\
\hline Manuscript ID: & APE-2010-0039.R1 \\
\hline Journal Selection: & Applied Economics \\
\hline $\begin{array}{r}\text { Date Submitted by the } \\
\text { Author: }\end{array}$ & 05-May-2011 \\
\hline Complete List of Authors: & $\begin{array}{l}\text { Jones, Peter; Robert Gordon University, Accounting Finance and } \\
\text { Economics }\end{array}$ \\
\hline JEL Code: & $\begin{array}{l}\text { B23 - Econometrics |Quantitative Studies < B2 - History of } \\
\text { Economic Thought since } 1925<\text { B }- \text { Schools of Economic Thought } \\
\text { and Methodology, C22 - Time-Series Models < C2 - Econometric } \\
\text { Methods: Single Equation Models < C - Mathematical and } \\
\text { Quantitative Methods, G33 - Bankruptcy|Liquidation < G3 - } \\
\text { Corporate Finance and Governance < G - Financial Economics }\end{array}$ \\
\hline Keywords: & $\begin{array}{l}\text { Creditors' voluntary liquidations, Forecasting, Macroeconomic } \\
\text { determinants, Government policy }\end{array}$ \\
\hline
\end{tabular}




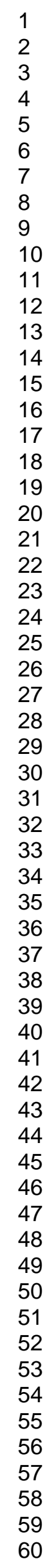

\section{SCHOLARONE ${ }^{m}$ \\ Manuscripts}

7

21

23

24

26

27

29

30

31

32

33

35

36

37

38

41

42

43

44

46

47

48

49

51

52

53

54

55

57

58

59

60 


\title{
The determinants of aggregate creditors' voluntary liquidations
}

\author{
Peter L. Jones*
}

This article investigates the determinants of creditors' voluntary liquidations (CVLs), an area of research that has received comparatively scant attention in the literature despite the fact that, at least in the UK, this form of insolvency has consistently comprised the majority of company failures. It develops an equilibrium correction model to explain variations in the aggregate number of creditors' voluntary liquidations in England and Wales between 1963 and 1995. This is then subjected to outof-sample testing over the subsequent ten-year period. The results indicate that in both the short-run and the long-run, changes in the level of liquidations can be explained by two main explanatory variables namely: the nominal after-tax cost of borrowing and changes in the overall level of economic activity. In addition, confirmatory evidence is provided of the dampening effect of the 1986 Insolvency Act on the number of liquidations. The model retains its forecasting accuracy in the out-of-sample period although there is possibly some preliminary evidence of a further mitigating effect associated with the Enterprise Act 2002.

\footnotetext{
*Aberdeen Business School, Robert Gordon University, Aberdeen, AB10 7QE, UK E-mail : p.jones@rgu.ac.uk
} 


\section{Introduction}

The empirical evidence regarding the factors that determine company failure has historically been divided into those studies whose primary focus is on company-specific characteristics such as financial performance and managerial efficiency and those whose main emphasis is on the macroeconomic determinants of aggregate failures. This study follows in the latter tradition.

Whilst the academic literature is replete with cross-sectional models which attempt to predict failure at the individual company level ${ }^{1}$, it remains the case that there is a relative paucity of time-series studies into the macroeconomic determinants of aggregate company failures. In order to identify the salient issues surrounding this topic, it would seem apposite to review the extant evidence within the context of the particular legal form of company failure being considered. In this respect, traditionally in the UK there have been two types of insolvency procedure, namely, compulsory and creditors' voluntary liquidations. ${ }^{2}$

An alternative procedure was introduced in the 1986 Insolvency Act whereby a company can be placed into administration rather than liquidation. An administration order is a means of using the protection of

\footnotetext{
${ }^{1}$ See Dimitras et al. (1996), Morris (1997) and more recently, Balcaen and Ooghe (2006) for excellent reviews of this literature.

2 The primary difference between the two procedures is that a compulsory liquidation is usually initiated by one of the company's creditors for non-payment of debts whilst the catalyst for a CVL is a decision by the directors that the company is in an insolvent position and can no longer continue to trade.
} 
the courts in order to provide a period of respite during which the company's affairs can be restructured. This was amended by the Enterprise Act 2002 which introduced changes to the procedure with Part II of the 1986 Insolvency Act being replaced with Schedule B1. These amendments included the introduction of additional routes into administration for companies that do not necessitate an administration order and also a streamlining of the process whereby, in some instances, companies can be dissolved without recourse to liquidation. These amendments came into force in September 2003.

Although there have been a number of studies into the determinants of compulsory liquidations (Hudson, 1986; Cuthbertson and Hudson, 1992; Turner et al., 1992); Sharabany, 2004; Fabling and Grimes, 2005), there is far less substantive empirical evidence regarding the incidence of CVLs. This, despite the fact this form of company liquidation has consistently accounted for more than $60 \%$ of all liquidations in England and Wales over the last forty years (see Fig. 1). In terms of the studies that have been undertaken, Hudson op. cit. suggests that the key determinant of the rate of CVLs is the share of non-oil and gas profits in company Gross Domestic Product (GDP), with real interest rates having a negative, but only marginally, significant influence. Meanwhile, Turner et al. (1992) identified the one-year lagged dependent variable and real gross trading profits as the primary influences on the rate of CVLs with the lagged level of the three-month inter-bank rate 
being of only marginal, positive significance. In addition, both a continuous and split time trend were found to be important explanatory factors.

\section{[INSERT FIGURE 1 APPROXIMATELY HERE]}

Some authors have not distinguished between different types of company failure in the manner identified above, preferring instead to adopt a more aggregated approach even though there are clearly distinct legal processes involved in the alternative forms of company insolvency. In this respect, Desai and Montes (1982) analysed business bankruptcies from a monetary perspective. Their results suggest that the number of failures is positively related to the lagged dependent variable and the prevailing level of nominal interest rates and negatively to the annual rate of growth in the money supply. Wadhwani (1986) identified the lagged liquidation rate, the nominal after-tax interest rate, real wages in manufacturing, real raw materials prices, a measure of company indebtedness and relative producer prices as having significant positive impacts on the rate of liquidations. In addition, world income, a fiscal stance variable and a time trend were significant negative influences. Perhaps the main finding of this study is that the inclusion of a nominal interest rate measure indicates a significant role for inflation in 
determining the probability of liquidation, implying the existence of imperfect capital markets. ${ }^{3}$

Wadhwani's model was re-estimated by Cornelius and Wright (1995) using quarterly data for the period 1965 to 1994 . The significant positive long-run impacts on the liquidation rate were found to be net firm debt to market value, producer price inflation and the real interest rate which was estimated on the basis of the yield on short-dated treasury bills. These results, at least partially confirm those of the Wadhwani study.

Davies (1987) applied Wadhwani's framework to annual business failures in the UK, US, Germany and Canada. The results indicate that the main significant influences on the annual rate of business failures were the level of nominal interest rates and changes in real GNP, real wages, real raw material prices and corporate debt to GNP. In addition, it was found that the US bankruptcy law of 1978 had reduced the costs of bankruptcy.

\footnotetext{
${ }^{3}$ This is based on the perspective that under perfect capital market conditions, firms can offset the negative cash flow effects of increases in expected inflation and hence nominal interest rates by borrowing more against the higher nominal value of their assets. As a consequence, the impact of inflation is essentially neutral.
} 
Young (1995) extended the work of Wadhwani by examining the impact of changes in the levels of both real and nominal interest rates on the solvency of the firm. In particular, a distinction is drawn between the effects of anticipated and unanticipated changes. The main influences on the liquidation rate were found to be: the lagged dependent variable; a measure of short-term debt to capital stock; the growth rate in the number of registered companies; the current level of aggregate demand; lagged real materials prices; the change in nominal interest rates; the lagged level of nominal interest rates; and three terms in unanticipated real interest rates. The inclusion of the nominal interest rate variables confirms the finding of Wadhwani in terms of the role of inflation in explaining the rate of company liquidations. In addition, unanticipated changes in real interest rates were found to have had a particularly significant effect during the period from the late 1970s to the mid 1980s when companies relied more heavily on variable rather than fixed-rate debt.

Vlieghe (2001a, 2001b) employed a variation of Wadhwani's model to analyse the key factors influencing the rate of corporate liquidations in the UK between 1975 and 1999. The key long-run explanatory factors were identified as being the proportion of net debt to GDP, the deviation of real GDP from trend, the real interest rate, real unit wages and the 1986 Insolvency Act. Furthermore, the short-run determinants were the nominal interest rate, the birth rate of new companies and property 
prices. Vlieghe also compared the factors responsible for the significant increase in the rate of liquidations during the period from 1988 to 1992 with those determining the subsequent decline between 1992 and 1997. The results indicate significant temporal variations in the nature of the key influences. Specifically, the single most important factor in explaining the increase in the liquidation rate was found to be the level of corporate indebtedness relative to GDP. In addition, declining GDP relative to trend as well as increasing real wages and real interest rates were also identified as being significant determinants. Moreover, the 1986 Insolvency Act was found to have had a dampening effect on the rise in the rate of corporate liquidations. In contrast, the key influence on the decline in the liquidation rate was the fall in real unit wage costs with the increase in GDP relative to trend and the reduction in the real interest rate over the period also being significant factors.

In light of the findings of the above studies regarding the role of aggregate debt levels in explaining total liquidations, Kearns (2003) examined the situation in Ireland. Concentrating primarily on the period of increasing corporate indebtedness between 1995 and 2002, he concluded that there was no definitive impact on the rate of insolvent liquidations as a result of the increasing corporate debt burden. However, this was a qualified conclusion as data availability problems prevented any formal statistical testing of the relationship. 
Liu and Wilson (2002) specifically tested for the effect of the introduction of the 1986 Insolvency Act on the overall rate of liquidations in the UK by means of an error (equilibrium) correction model (ECM). The findings confirmed that this legislation was a significant factor in reducing the liquidation rate up until the beginning of 1990. Other important determinants were found to be the lagged dependent variable, the level of interest rates, lending to the corporate sector, the level of inflation, corporate profitability and the company birth rate. These results were largely confirmed by Liu (2004).

In a similar vein to Fabling and Grimes op. cit., Gaffeo and Santoro (2006) examine business failure from a regional perspective using annual data for the twenty Italian regions. Employing a panel cointegration approach they identified significant long-run relationships between trend output, vertical interest spreads, a measure of 'surprise' inflation and the rate of company liquidations. Specifically, the former was found to be negatively related to the failure rate and the latter two impacted positively. In addition, their results also indicate that changes in both real wages and the new business formation rate were significant positive influences during the movement to the long-run equilibrium position.

Finally, Rose et al. (1982) modelled business failure in the US and hypothesised a generalised linear model whereby the failure rate was linked to external factors related to the business cycle. The independent 
variable set reflected the alternative theoretical explanations of failure and included leading and coincident indicators as well as supply or costpush, monetary and savings-investment variables. The rate of business failure was found to be positively related to the lagged value of the S \& P composite index, the contemporaneous ratio of retail sales to GDP and the lagged ninety-day Treasury bill rate. Those factors exerting a significant negative impact were identified as the lagged prime interest rate, lagged gross private domestic investment as a proportion of GNP and a measure of after-tax company profitability.

The findings of these studies enable us to identify the key debates in relation to the determinants of company liquidations that will form the basis of the analysis presented here. Firstly, it is apparent that there is some dubiety concerning the role of interest rates in terms of the relative importance of real and nominal rates as well as the significance of levels or changes. Secondly, there appears to be no general consensus regarding the relative importance of general macroeconomic conditions, company sector performance and input-cost considerations within the failure process. Finally, the use of the number of company births as a means of capturing the 'age-structure' effect associated with company failure represents another potentially contentious issue given the alternative 


\footnotetext{
${ }^{4}$ See Love (1995) and Audretsch and Fritsch (1995) for an informative discussion of the relative merits of the 'ecological' and 'labour market' approaches to the measurement of entry rates.
}

\section{Theoretical Framework}

The theoretical framework employed in this study is based on that used by Vlieghe (2001a, 2001b), Sharabany (2004), Fabling and Grimes (2005) and Gaffeo and Santoro (2006) amongst others who, in turn, employ variants of the approach adopted by Wadhwani (1986). 
Firstly, the nominal level of pre-tax profits for the $k$ th firm in time period $t,\left(\mathrm{P}_{k t}\right)$ is given by:

$$
P_{k t}=R_{k t}-W_{k t}-M_{k t}-i_{t} D_{k t}
$$

Where $\mathrm{R}_{k t}$ is nominal total revenue, $\mathrm{W}_{k t}$ represents the level of wage costs, $\mathrm{M}_{k t}$ is the cost of material inputs, $i_{t}$ is the prevailing nominal interest rate and $\mathrm{D}_{k t}$ is the firm's level of indebtedness.

Assuming that the liquidation process will be initiated by the directors when the firm's net asset value (or net worth) becomes negative and letting $\mathrm{V}_{k t}$ represent the net asset value of the $k$ th firm, then the liquidation condition is given by:

$$
V_{k t}+P_{k t}<0
$$

Combining (1) and (2) and denoting real constructs in lower case terms whilst retaining the nominal interest rate $i_{t}$ yields:

$$
v_{k t}+r_{k t}-w_{k t}-m_{k t}-i_{t} d_{k t}<0
$$

Furthermore, real total revenue is assumed to be a direct function of real aggregate economic activity $\left(y_{t}\right)$, the rate of inflation $\left(\Pi_{t}\right)$ as well 
as a random disturbance term $\left(\varepsilon_{k t}\right)$. Clearly, it would be expected that economic activity would be positively correlated with total revenue and ceteris paribus, firm profitability. As far as the role of inflation is concerned Wadhwani (1986) identified that where borrowing limits exist, firms that have exceeded their limit will face increasing pressures on internally generated cash flows. With non-indexed variable rate debt, for a given level of real interest rates, an increase in the rate of inflation will result in a proportionately larger increase in the nominal interest rate. As Davis (1987) identifies, this effect can be captured by incorporating both nominal and real interest rates into the modelling procedure. This is taken into account in (3) above and consequently does not have to be considered independently.

One of the interesting features of the aggregate company failure literature is that the role of company taxation is largely ignored. For example, Vlieghe (2001a) refers to the potential impacts but does not incorporate a tax variable into the modelling process. However, Wadwhani op. cit. did examine the role of taxation by means of the aftertax cost of borrowing and found the nominal cost to be a significant explanatory factor under conditions of both perfect and imperfect competition. This approach is replicated here and again, the nature and significance of any impact can be analysed by means of the interest rate term in (3). 
Thus, real total revenue for the $k$ th firm in period $t$ is denoted by:

$$
r_{k t}=\alpha_{1} y_{t}-\alpha_{2} \Pi_{t}+\varepsilon_{k t}
$$

The combination of (3) and (4) indicates that firm $k$ will face liquidation when the following pertains:

$$
\varepsilon_{k t}<i_{t} d_{k t}+w_{k t}+m_{k t}-v_{k t}-\alpha_{1} y_{t}+\alpha_{2} \Pi_{t}
$$

Therefore, the probability of the directors of firm $k$ initiating a creditors' voluntary liquidation in period $t,\left(\mathrm{PCVL}_{k t}\right)$ is given by:

$$
\operatorname{PCVL}_{k t}=f\left(i_{t}, d_{k t}, w_{k t}, m_{k t}, v_{k t}, y_{t}, \Pi_{t}\right)
$$

which implies that the aggregate economy-wide number of creditors' voluntary liquidations $\left(\mathrm{CVL}_{t}\right)$ can be expressed as:

$$
\mathrm{CVL}_{t}=g\left(i_{t}, d_{t}, w_{t}, m_{t}, v_{t}, y_{t}, \Pi_{t}, \mathbf{X}_{t}\right)
$$

where $\mathbf{X}_{t}$ is a vector of non-stochastic variables specifically consisting in this study of dummy explanatory variables designed to capture the potential impacts of the 1981 Civil Service Strike, the Insolvency Act of 1986 and seasonal variations in the dependent variable. 


\section{Variable selection and methodology}

A detailed description of the variables used in the modelling process is provided in the appendix. The change in the number of CVLs in England and Wales between 1963Q1 and 1995Q4 is taken to be the dependent variable rather than the liquidation rate due to the lack of published quarterly data on the stock of companies over the estimation period. Furthermore, company 'births' are also excluded from the analysis for the same reason.

As suggested in the preceding section, two interest rate measures $\left(i_{t}\right)$ are employed, the base rate $(I R)$ and a proxy for the after-tax cost of debt financing $(\operatorname{COSTD})$. The latter is used in order to reflect the fact that many companies fail for reasons other than lack of profitability and, consequently, the tax-shield effect associated with the use of debt constitutes a potentially significant explanatory factor.

Secondly, corporate indebtedness $\left(d_{t}\right)$ is measured by means of both the company net borrowing requirement (NBR) and the level of company bank borrowing $(B A N K B)$.

Two measures of real wages $\left(w_{t}\right)$ are employed namely: the IMF index of relative unit labour costs in manufacturing (RULC) and the general index of unit labour costs (GULC) which is defined as whole economy average wages and salaries divided by output per worker. The 
cost of material inputs $\left(m_{t}\right)$ is measured by the index of relative producer prices $(R E L P P)$.

As far as the aggregate net asset value or net worth is concerned $\left(v_{t}\right)$ the Office for National Statistics publishes figures for changes in net worth for private sector non-financial corporations however, the series only dates back until 1965. Therefore, the overall company financial surplus/deficit position (SURDEF) is used as a proxy (the correlation between the two series is 0.88 ).

Real aggregate economic activity $\left(y_{t}\right)$ and the rate of inflation $\left(\Pi_{t}\right)$ are measured by GDP and the Retail Prices Index (RPI) respectively. Finally, the vector of non-stochastic variables $\left(\mathbf{X}_{t}\right)$ includes a dummy variable designed to assess the influence of the 1986 Insolvency Act (1986DUM) which is assigned a value of 1 between 1986Q4 and 1990Q4 and 0 elsewhere. A dummy variable is also used in order to take account of the effects of the 1981 Civil Service strike (1981DUM) and the 'missing data' problem is addressed by means of a zero-order approach (Pindyck and Rubinfeld, 1991).

Summary descriptive statistics for both the dependent variable and the explanatory variables are provided in Table 1. As far as the former is concerned, the number of CVLs has increased steadily, particularly since the early 1980s, reaching a maximum of 3867 in the 
third quarter of 1992. The main feature of the statistics for the independent variables is perhaps the volatility exhibited by the company indebtedness measures reflecting the diverse nature of the macroeconomic conditions experienced in the UK during the estimation period.

\section{[INSERT TABLE 1 APPROXIMATELY HERE]}

The data were tested for the presence of unit roots by means of both the augmented Dickey-Fuller (ADF) and Phillips-Perron (PP) test statistics the results for which are detailed in Table 2. Unsurprisingly, the null hypothesis of a unit root cannot be rejected in the majority of cases and, as a consequence, the modelling approach employed is the EngleGranger two-step procedure.

\section{[INSERT TABLE 2 APPROXIMATELY HERE]}

The general-to-specific methodology of Hendry and Doornik (2001) was adopted and the final estimating equation is given by:

$$
\Delta C V L_{t}=c+a_{1}(L) \Delta C V L_{t}+a_{2}(L) \Delta X_{t}+a_{3}(L) X_{t}+\gamma \varphi_{t-1}+\mu_{t}
$$

Where: $a_{\mathrm{i}}(\mathrm{L})$ are polynomials in the lag operator; $a_{1}$ is the estimated regression coefficient on the lagged dependent variable; $a_{2}$ and $a_{3}$ are the 
estimated regression coefficients on changes in, and levels of, the lagged independent variables respectively; $\varphi_{t-1}$ is the cointegrating vector and $\gamma$ is the associated estimated coefficient; $c$ is a constant term; and $\mu_{t}$ is an error term. This formulation is broadly equivalent to that employed by Vlieghe (2001a, 2001b).

\section{Empirical analysis and discussion}

The estimation results and diagnostic statistics for the preferred specification are detailed in Table 3. All of the estimated regression coefficients are statistically significant at the 0.05 level or better and the associated signs are intuitively plausible. Furthermore, all of the diagnostic tests are satisfactory. It is evident that the two main macroeconomic determinants of the change in CVLs are the lagged changes in GDP and the one-period lagged level of the nominal after-tax cost of debt (COSTD). The former observation is generally in accordance with the findings of Cuthbertson and Hudson (1992) for UK compulsory liquidations.

[INSERT TABLE 3 APPROXIMATELY HERE]

The inclusion of the nominal after-tax cost of debt in the model in preference to the real measure tends to confirm the results of both Wadhwani (1986) and Young (1995) amongst others concerning both the significance of inflation in contributing to company liquidations and the 
existence of imperfect capital markets. In addition, the fact that it is significant in levels rather than differences implies that any change in the rate of inflation is likely to have a long-run impact on the level of CVLs. Finally, the after-tax formulation suggests that the small-firm corporation tax rate does influence the level of liquidations. Specifically, a higher rate of corporation tax, will, ceteris paribus, produce a greater tax-shield effect which, in turn, results in a lower after-tax cost of debt. As a consequence, the probability of failure amongst tax-paying firms will be reduced.

It should also be noted that the relatively short lag structures associated with these two variables would appear to indicate that the decision by the directors to initiate a CVL is taken on the basis of shortterm economy-wide influences. In addition, this could be symptomatic of the acute vulnerability of the firms involved to both short-term downturns in economic growth and/or increases in the after-tax cost of borrowing. Alternatively, it may simply reflect the fact that the initial formal phases of a CVL can generally be completed in a comparatively short period of time.

The significance of the 1986 Insolvency Act dummy variable provides further confirmatory evidence that this legislation had a dampening effect on the number of liquidations. In this instance, the coefficient value implies that the short-run effect was a reduction of $11.07 \%$. This is of the same order of magnitude as the reduction of $8.6 \%$ 
estimated by Vlieghe (2001a) and considerably larger than the figures reported in both Cuthbertson and Hudson (1992) and Liu and Wilson (2002).

The coefficient on the error correction term of -0.21 implies convergence to the long-run equilibrium at a rate of $21 \%$ per quarter which again is broadly similar to the rate reported in Vlieghe (2001a, 2001b). Finally, the significant positive coefficient on the seasonal dummy variable indicates that there is a tendency for the number of CVLs to be higher in the first quarter of the year.

The solved static long-run regression equation is detailed below ( $t$ statistics in parentheses):

$$
\begin{aligned}
& C V L=-0.111-5.177(G D P)+0.085(C O S T D)-0.097(1986 D U M) \\
& (-2.42) \quad(-4.44) \\
& +0.081(Q 1 D U M)
\end{aligned}
$$

Wald statistic $=69.32(0.000)$

It is evident from the above that all of the long-run coefficients are well determined and the Wald test statistic indicates that the null hypothesis that they are all zero (except the constant) is rejected. The above formulation illustrates the dominant long-run impact of economic 
growth on the number of CVLs and the estimated coefficient is again consistent with that reported in Vlieghe (2001a, 2001b). Moreover, the significance of the 1986 Insolvency Act indicates that this legislation has had a long-term impact on the number of CVLs which is consistent with the findings of Liu (2002).

The Chow test of statistical parameter constancy and a forecast test of numerical parameter constancy (Hendry and Doornik, 2001) were employed in order to further assess the robustness of the estimated model. The results are detailed in Table 4 and they clearly indicate that the null hypotheses of both statistical and numerical parameter constancy cannot be rejected for any of the test periods.

\section{[INSERT TABLE 4 APPROXIMATELY HERE]}

Finally, the out-of-sample forecasting performance of the model was tested over the ten year period 1996Q1 to 2005Q4 by means of Theil's $\mathrm{U}$ statistic and the associated decomposition advocated by Granger and Newbold (1973). The test statistic for the period is 0.04 which is sufficiently close to zero so as to suggest reasonably effective forecasting accuracy. Decomposing this measure into the proportions of inequality produces a bias proportion of 0.05 , a variance proportion of 0.02 and a covariance proportion of 0.93 . These figures indicate respectively, that the degree of systematic error is relatively low, the variability in the actual 
series is largely being replicated in the forecast series and, as a consequence, deviations between the actual and fitted values are primarily due to unsystematic errors. This out-of-sample accuracy is confirmed by the root-mean-square percentage error of $8.1 \%$. Whilst it is not possible to compare this performance with the vast majority of previous studies due to the lack of out-of-sample testing, Turner et al. (1992) did produce ex post forecasts for the rate of CVLs between 1980 and 1989. The reported mean absolute error was 36\%. Finally, plots of both the actual and fitted values of the number of CVLs for both the estimation and forecast periods are provided in Fig. 2.

\section{[INSERT FIGURE 2 APPROXIMATELY HERE]}

In general, the graph illustrates that the forecast values track the actual values extremely closely over the entire period thereby reinforcing the preceding analysis and evaluation. However, one caveat should be introduced at this stage in relation to the performance of the model in light of the introduction of the amendments enshrined in the Enterprise Act 2002 during the third quarter of 2003. Since this date it can be seen that the model appears to exhibit a tendency to over-predict the actual number of CVLs. Although the root-mean-square percentage errors for the pre- and post- 2003Q3 forecasts of $8.03 \%$ and $8.16 \%$ respectively are virtually identical, it may be that the changes in the legislation could have a further dampening effect on the number of CVLs. Indeed, the number 
of companies in England and Wales entering administration under the provisions of the 2002 Act has increased from 1,601 in 2004, the first full year of operation, to 3,560 in 2006. However, clearly a longer time period is required before definitive conclusions can be drawn regarding this potential effect.

\section{Conclusions}

This article has investigated a somewhat neglected aspect of the analysis of company failure, namely, the key factors affecting the level of aggregate CVLs in England and Wales. The rationale for limiting the study to this particular legal form of failure is that CVLs have consistently represented the largest proportion of all company liquidations. The results indicate that the two main significant macroeconomic determinants are the rate of economic growth and the level of nominal, after-tax interest rates. This latter finding lends support to the view that nominal factors have a significant influence on company liquidations and can be further interpreted as providing evidence to support the existence of imperfect capital markets. These two macroeconomic influences were found to be significant in both the shortand long-run.

In addition, the final estimated equation includes a dummy variable for the 1986 Insolvency Act confirming the evidence from some 
of the previous studies that this legislation has had a dampening effect on the number of liquidations.

The within- and out-of-sample performance of the model was tested and the results of the latter in particular suggest that the parsimonious equation reported here provides a reasonably effective means of capturing variations in, and hence forecasting the level of CVLs over time. However, the model did exhibit a tendency to over-predict during the period since the third quarter of 2003 suggesting that the change in insolvency legislation incorporated in the Enterprise Act 2002 may have had a further mitigating effect on the number of CVLs.

Clearly, there are a number of policy implications arising from this analysis. Firstly, in terms of limiting the number of CVLs, it is imperative that government policy is directed at providing an environment of macroeconomic stability which reduces the likelihood of significant reductions in economic growth. Secondly, in terms of the macroeconomic policy instruments, the evidence suggests that it is the conjoint impact of the level of nominal interest rates and the small firm corporation tax rate that are the primary influences on the level of CVLs. This implies that, where a policy of lower interest rates is combined with one of reducing the corporation tax rate levied on small businesses, then, ceteris paribus, the resultant decrease in the number of CVLs will be at least partially 
tempered by the impact of a reduction in the tax shield caused by the latter. 


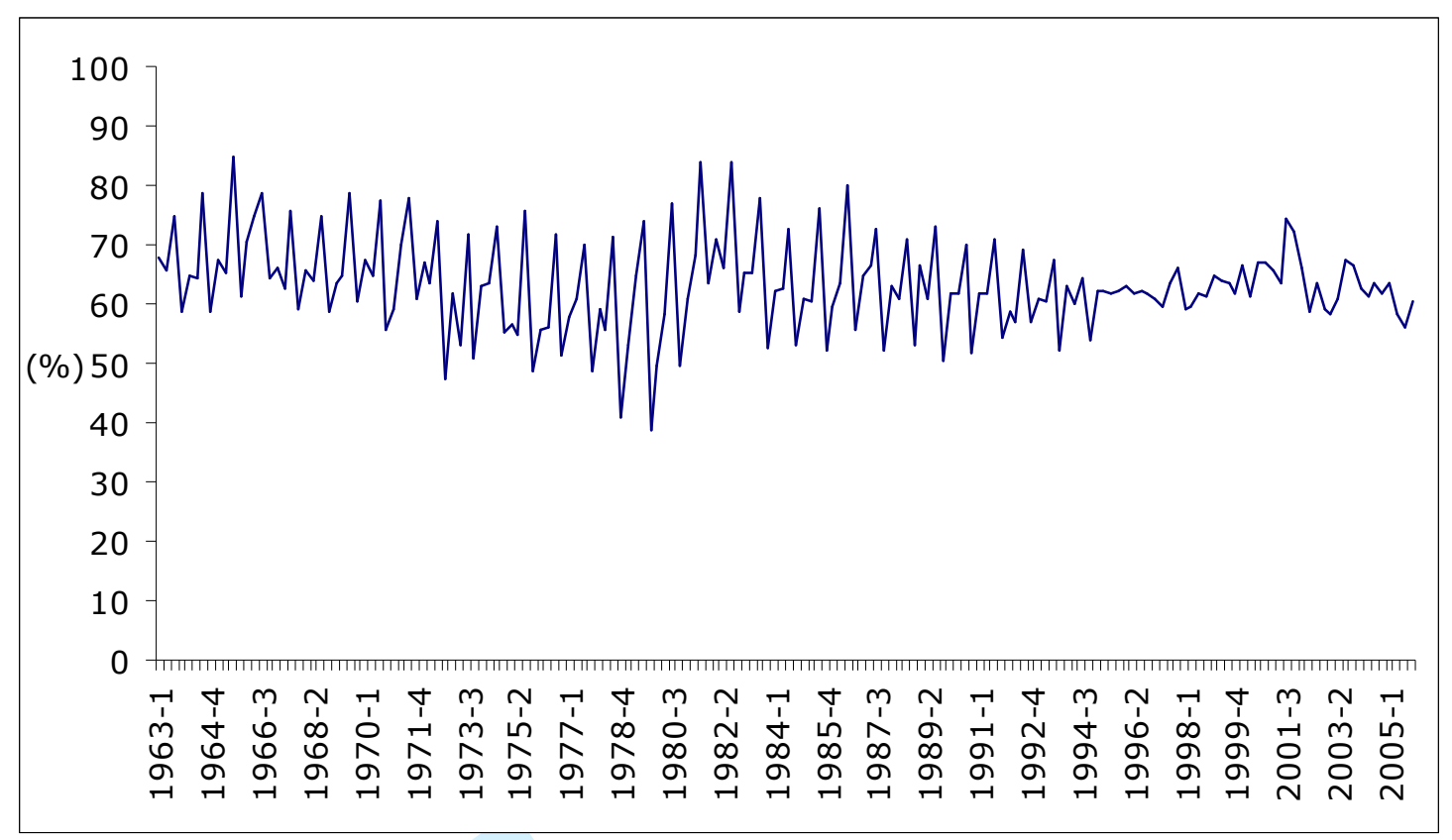

Fig. 1. Ratio of creditors' voluntary liquidations to total liquidations in England and Wales, 1963 (Q1) to 2005 (Q4) 


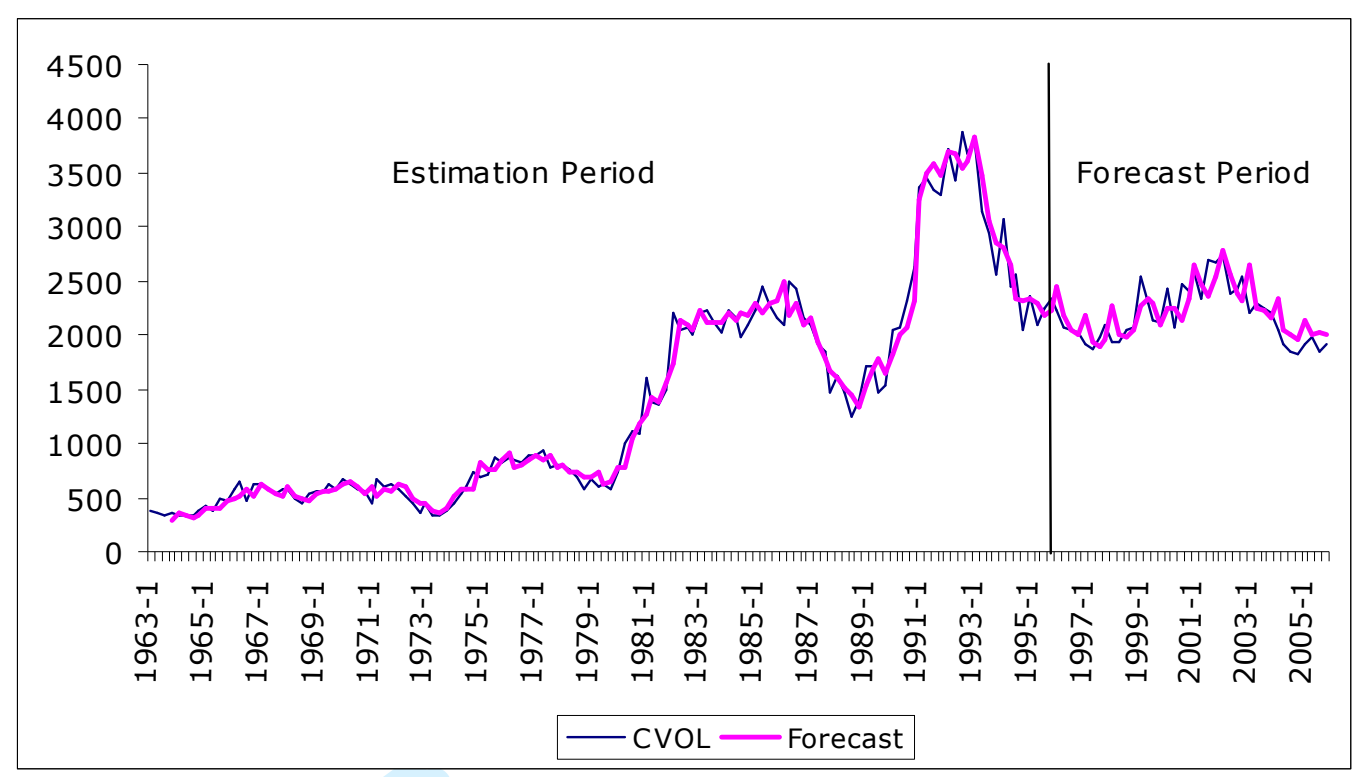

Fig. 2. Actual and forecast numbers of creditors' voluntary liquidations in England and Wales, 1963 (Q1) to 2005 (Q4) 
Table 1. Descriptive statistics

\begin{tabular}{lrrrr}
\hline Variable & Mean & SD & Minimum & Maximum \\
\hline CVL & 1372.60 & 965.69 & 325.00 & 3867.00 \\
IR $(\%)$ & 8.21 & 2.92 & 3.36 & 14.28 \\
COSTD $(\%)$ & 6.12 & 2.30 & 2.40 & 11.30 \\
NBR $(£ \mathrm{~m})$ & 2947.60 & 3621.10 & -4911.20 & 15417.00 \\
BANKB $(£ \mathrm{~m})$ & 1732.20 & 2310.60 & -2988.00 & 10561.00 \\
RULC $(1990=100)$ & 93.06 & 12.37 & 69.20 & 132.50 \\
GULC $(2003=100)$ & 37.18 & 25.93 & 7.30 & 80.80 \\
RELPP $(1990=100)$ & 92.19 & 8.49 & 69.60 & 110.50 \\
SURDEF $(£ \mathrm{~m})$ & -28.46 & 1969.40 & -6327.80 & 4289.00 \\
GDP $(1990=100)$ & 77.90 & 15.84 & 50.00 & 107.50 \\
$\triangle R P I(\%)$ & 7.71 & 5.49 & 1.30 & 26.60 \\
& & & & \\
\hline
\end{tabular}


Table 2. Unit root tests

\begin{tabular}{|c|c|c|c|c|}
\hline \multirow[t]{2}{*}{ Variable } & \multicolumn{2}{|c|}{ Level } & \multicolumn{2}{|c|}{ First difference } \\
\hline & ADF & PP & ADF & PP \\
\hline$C V L$ & -1.50 & -1.26 & $-4.34^{* * *}$ & $-13.05^{* * *}$ \\
\hline$I R$ & $-2.62^{*}$ & $-2.73^{*}$ & $-10.65^{* * *}$ & $-10.65^{* * *}$ \\
\hline COSTD & -2.55 & $-2.61^{*}$ & $-10.40^{* * *}$ & $-10.40^{* * *}$ \\
\hline$N B R$ & -2.38 & $-8.74^{* * *}$ & $-6.94^{* * *}$ & $-25.25^{* * *}$ \\
\hline$B A N K B$ & $-3.53^{* * *}$ & $-6.70^{* * *}$ & $-10.98^{* * *}$ & $-19.88^{* * *}$ \\
\hline RULC & -2.09 & -2.03 & $-9.69^{* * *}$ & $-9.68^{* * *}$ \\
\hline GULC & $-3.31^{* *}$ & $-3.41^{* *}$ & $-14.06^{* * *}$ & $-14.03^{* * *}$ \\
\hline RELPP & -2.37 & -2.25 & $-9.97^{* * * *}$ & $-9.98^{* * * *}$ \\
\hline SURDEF & $-3.75^{* * *}$ & $-9.71^{* * *}$ & $-5.34^{* * *}$ & $-32.82^{* * *}$ \\
\hline GDP & -0.65 & -1.39 & $-5.11^{* * *}$ & $-11.61^{* * *}$ \\
\hline$R P I$ & -2.06 & -2.05 & $-4.82^{* * *}$ & $-8.19^{* * *}$ \\
\hline
\end{tabular}


Table 3. Determinants of creditors' voluntary liquidations

\begin{tabular}{|c|c|c|}
\hline Explanatory variables & $\begin{array}{c}\text { Estimated } \\
\text { coefficients }\end{array}$ & $t$-statistics ${ }^{a}$ \\
\hline Constant & -0.135 & $-2.02 * *$ \\
\hline$\Delta_{1} \ln (C V L)_{t-2}{ }^{\mathrm{b}}$ & -0.208 & $-2.76^{* * *}$ \\
\hline$\Delta_{1} \ln (\mathrm{GDP})_{t-2}$ & -3.140 & $-3.12 * * *$ \\
\hline$\Delta_{1} \ln (\mathrm{GDP})_{t-3}$ & -3.115 & $-2.99 * * *$ \\
\hline $\ln (\operatorname{COSTD})_{t-1}$ & 0.102 & $2.89 * * *$ \\
\hline 1986DUM & -0.117 & $-3.29 * * *$ \\
\hline$\varphi_{t-1}$ & -0.210 & $-5.32 * * *$ \\
\hline Q1DUM & 0.097 & $4.31^{* * *}$ \\
\hline \multicolumn{3}{|l|}{ Diagnosticsc: } \\
\hline Adjusted R² & 0.4185 & \\
\hline Standard Error & 0.11 & \\
\hline Model F-Test $(7,121)$ & $12.44(0.00)$ & \\
\hline$Z_{1}(5,116)$ & $1.50(0.20)$ & \\
\hline $\mathrm{Z}_{2}(4,113)$ & $0.38(0.83)$ & \\
\hline $\mathrm{Z}_{3}(2)$ & $1.86(0.39)$ & \\
\hline $\mathrm{Z}_{4}(12,108)$ & $1.55(0.12)$ & \\
\hline $\mathrm{Z}_{5}(33,87)$ & $1.04(0.43)$ & \\
\hline $\mathrm{Z}_{6}(1,120)$ & $0.40(0.53)$ & \\
\hline
\end{tabular}

Notes: ${ }^{* *}=p<0.05$ and ${ }^{* * *}=p<0.01$

a $t$-statistics based upon White's (1980) asymptotic heteroscedastic consistent covariance matrix estimates.

$\mathrm{b}$ The jth-difference operator is defined as, $\Delta_{\mathrm{j}} \mathrm{X}_{t}=\mathrm{X}_{t}-\mathrm{X}_{t-\mathrm{j}}$

${ }^{c} Z_{1}$ is the $F$-form of the Lagrange multiplier test for first order serial correlation of the residuals. $Z_{2}$ is the $A R C H$ test. $Z_{3}$ is a test for normality of the residuals, see Hendry and Doornik (2001). $Z_{4}$ is the White test for heteroscedasticity. $Z_{5}$ is a general test for functional form misspecification/heteroscedastic errors. $Z_{6}$ is the RESET test due to Ramsey (1969). 
Table 4. Parameter estimates and constancy tests

\begin{tabular}{lcccccc}
\hline Period & $\Delta_{1} \ln (\mathrm{GDP})_{t-2}$ & $\Delta_{1} \ln (\mathrm{GDP})_{t-3}$ & $\ln (\text { COSTD })_{t-1}$ & 1986 UUM & $\begin{array}{c}\text { Chow } \\
\text { test }\end{array}$ & $\begin{array}{c}\text { Forecast } \\
\text { test }\end{array}$ \\
\hline 1964(Q1) - 1982(Q4) & -3.296 & -3.240 & 0.085 & & 0.59 & 36.48 \\
& $(-2.87)$ & $(-2.56)$ & $(1.77)$ & & {$[0.98]$} & {$[0.95]$} \\
$1964(\mathrm{Q} 1)-1984(\mathrm{Q} 4)$ & -3.141 & -3.211 & 0.083 & & 0.73 & 37.32 \\
& $(-2.82)$ & $(-2.75)$ & $(1.86)$ & & {$[0.87]$} & {$[0.75]$} \\
$1964(\mathrm{Q} 1)-1986(\mathrm{Q} 4)$ & -2.904 & -3.090 & 0.089 & -0.092 & 0.54 & 21.60 \\
& $(-2.88)$ & $(-3.06)$ & $(2.35)$ & $(-4.95)$ & {$[0.98]$} & {$[0.97]$} \\
$1964(\mathrm{Q} 1)-1988(\mathrm{Q})$ & -2.889 & -3.149 & 0.092 & -0.143 & 0.59 & 19.36 \\
& $(-2.70)$ & $(-2.96)$ & $(2.36)$ & $(-3.91)$ & {$[0.94]$} & {$[0.89]$} \\
$1964(\mathrm{Q} 1)-1990(\mathrm{Q})$ & -3.074 & -3.092 & 0.097 & -0.114 & 0.40 & 8.61 \\
& $(-2.88)$ & $(-2.91)$ & $(2.59)$ & $(-3.12)$ & {$[0.99]$} & {$[0.99]$} \\
$1964(\mathrm{Q} 1)-1992(\mathrm{Q} 4)$ & -3.024 & -3.103 & 0.095 & -0.113 & 0.53 & 6.85 \\
& $(-2.92)$ & $(-2.99)$ & $(2.64)$ & $(-3.14)$ & {$[0.89]$} & {$[0.87]$} \\
$1964(\mathrm{Q} 1)-1994(\mathrm{Q} 4)$ & -3.136 & -3.103 & 0.101 & -0.117 & 0.27 & 1.09 \\
& $(-3.08)$ & $(-2.97)$ & $(2.87)$ & $(-3.27)$ & {$[0.90]$} & {$[0.90]$} \\
\hline
\end{tabular}

Note: (.) are the $t$-statistics and [.] are the marginal significance levels. 


\section{Appendix: Data definitions and sources}

\begin{tabular}{|c|c|c|}
\hline Description & Definition & Source \\
\hline $\begin{array}{l}\text { Creditors' voluntary liquidations } \\
\text { (CVL) }\end{array}$ & The number of liquidations, unadjusted. & Financial Statistics \\
\hline Interest Rate (IR) & Base Rate: Selected Retail Banks & Financial Statistics \\
\hline Cost of Debt (COSTD) & $\begin{array}{l}\text { Base Rate x (1 - Small Firm Corporation Tax } \\
\text { Rate). }\end{array}$ & \\
\hline NBR & Company net borrowing requirement $(£ \mathrm{~m})$. & Financial Statistics \\
\hline BANKB & Company Bank Borrowing ( $\mathrm{Em})$ & Financial Statistics \\
\hline $\begin{array}{l}\text { Relative Unit Labour Costs } \\
\text { (RULC) }\end{array}$ & $\begin{array}{l}\text { The IMF index of relative unit labour costs in } \\
\text { manufacturing }(1990=100) \text {. }\end{array}$ & Economic Trends \\
\hline Unit Labour Costs (GULC) & $\begin{array}{l}\text { The general index of unit labour costs }(2003= \\
100) \text {. }\end{array}$ & Economic Trends \\
\hline Producer Prices (RELPP) & $\begin{array}{l}\text { The index of relative producer prices }(1990= \\
\text { 100). }\end{array}$ & Economic Trends \\
\hline Funding (SURDEF) & Company financial surplus/deficit ( $€ \mathrm{~m})$. & Financial Statistics \\
\hline $\begin{array}{l}\text { Gross Domestic Product } \\
\text { (GDP) }\end{array}$ & $\begin{array}{l}\text { Gross Domestic Product (output measure } 1990 \\
=100 \text { ) }\end{array}$ & Economic Trends \\
\hline Inflation (RPI) & Retail Prices Index $(1995=100)$ & Economic Trends \\
\hline $\begin{array}{l}\text { Insolvency Act of } 1986 \\
\text { (1986DUM) }\end{array}$ & $\begin{array}{l}\text { Dummy variable of } 1 \text { from 1986Q4 to 1990Q4 } \\
\text { and } 0 \text { elsewhere. }\end{array}$ & \\
\hline $\begin{array}{l}\text { 1981 Civil Service Strike } \\
\text { (1981DUM) }\end{array}$ & $\begin{array}{l}\text { Dummy variable of } 1 \text { for } 1981(Q 2) \text { and } \\
\text { 1981(Q3), } 0 \text { elsewhere. }\end{array}$ & \\
\hline
\end{tabular}




\section{References}

Audretsch, D.B. and Fritsch, M. (1995) The measurement of entry rates: reply, Empirica 22, 159-161.

Balcaen, S. and Ooghe, H. (2006) 35 years of studies on business failure: an overview of the classic statistical methodologies and their related problems, The British Accounting Review, 38, 63-93.

Cornelius, M. and Wright, K. (1995) Company insolvencies and inflation, Bank of England Quarterly Bulletin, 274-275.

Cuthbertson, K. and Hudson, J. (1992) The determination of compulsory liquidations in the UK: 1972-1989, Department of Economics, Universities of Newcastle upon Tyne and Bath and Economics Division, Bank of England Working Paper No. 92-01.

Davis, E.P. (1987) Rising sectoral debt/income ratios: a cause for concern?, BIS Economic Papers, No. 20.

Desai, M.J. and Montes, D.E. (1982) A macroeconomic model of bankruptcies in the British economy, 1945-1980, British Review of Economic Issues 4, 1-14. 
Dimitras, A.I., Zanakis, S.H. and Zopounidis, C. (1996) A survey of business failures with an emphasis on prediction methods and industrial applications, European Journal of Operational Research, 90, 487-513.

Fabling, R. and Grimes, A. (2005) Insolvency and economic development: regional variation and adjustment, Journal of Economics and Business, 57, 339-359.

Gaffeo, E. and Santoro, E. (2006) Macroeconomic conditions and business failures in Italy: a panel cointegration approach, Paper delivered at Dipartimento di Economia, Universita Degli Studi di Trento, December 14-15.

Granger, C.W.J and Newbold, P. (1973) Some comments on the evaluation of economic forecasts, Applied Economics, 5, $35-47$.

Hendry, D.F. and Doornik, J.A. (2001) Empirical Econometric Modelling Using PcGive, London: Timberlake Consultants Ltd.. 
Hudson, J. (1986) An analysis of company liquidations, Applied Economics, 18, 219-235.

Kearns, A. (2003) Corporate indebtedness and liquidations in Ireland, Quarterly Bulletin, 91-105.

Liu, J. and Wilson, N. (2002) Corporate failure Rates and the impact of the 1986 Insolvency Act: an econometric analysis, Managerial Finance, 28, 61-71.

Liu, J. (2004) Macroeconomic determinants of corporate failures: evidence from the UK, Applied Economics, 36, 939945.

Love, J. H. (1995) The measurement of entry rates: reconsideration and resolution, Empirica 22, 151-157.

Morris, R. (1997) Early Warning Indicators of Corporate

Failure: A Critical Review of Previous Empirical Research and Further Empirical Evidence, Aldershot: Ashgate.

Pindyck, R.S. and Rubinfeld, D.L. (1991) Econometric Models $\mathcal{E}$ Economic Forecasts, McGraw-Hill, New York. 
Ramsey, J.B. (1969) Tests for specification errors in classical least squares regression analysis, Journal of the Royal Statistical Society, Series B, 31, 350-371.

Rose, P.S., Andrews, W.T. and Giroux, G.A. (1982)

Predicting business failure: a macroeconomic perspective, Journal of Accounting, Auditing and Finance, 6, 20-31.

Sharabany, R. (2004) Business failures and macroeconomic risk factors, Discussion Paper No. 2004.06, Bank of Israel.

Turner, P., Coutts A. and Bowden, S. (1992) The effect of the Thatcher government on company liquidations: an econometric study, Applied Economics, 24, 935-943.

Vlieghe, G.W. (2001a) Indicators of fragility in the UK corporate sector, Bank of England Working Paper, No. 146.

Vlieghe, G.W. (2001b) Corporate liquidations in the United Kingdom, Financial Stability Review, 141-147.

Wadhwani, S.B. (1986) Inflation, bankruptcy, default premia and the stock market, The Economic Journal, 96, 120138. 
White, H. (1980) A heteroscedasticity - consistent

covariance Matrix estimator and direct test for heteroscedasticity', Econometrica, 48, 817-838.

Young, G. (1995) Company liquidations, interest rates and debt, The Manchester School Supplement, 63, 57-69. 